\title{
Pengembangan Penuntun Praktikum Sma Yang Inovatif Dan Interaktif Terintegrasi Discovery Learning (Pembelajaran Penemuan) Pada Materi Kimia Unsur
}

\author{
Fitri Anggraini ${ }^{1)}$, Ramlan Silaban ${ }^{2)}$, Iis Siti Jahro ${ }^{2)}$ \\ ${ }^{1)}$ STIKOM Tunas Bangsa / Alumni Program Studi Pendidikan Kimia Pascasarjana UNIMED \\ ${ }^{2)}$ Dosen Jurusan Kimia FMIPA dan Program Pascasarjana UNIMED \\ Email : fitrianggraini@stikomtb.ac.id
}

\begin{abstract}
This research aims to develop practical guidance SMA innovative and integrated interactive discovery learning on chemical material element of class XII corresponding semester of education unit level curriculum (KTSP). This research is a research and development (research and development) and experiment. Results of study using lab guides that have been developed in the measure by the end of the study. Research and development (research and development) is the research that used to result in specific product and test the effectiveness of the product. Guidance lab that already exists and which has been developed and then validated by 2 respondents chemistry professor, State University of Medan and 25 respondents high school chemistry teacher. For practical guidance that already exists gained an average value for the validation professor of 4.04 and an average value for the validation of teachers 3.80. For practical guidance that has been developed gained an average value for the validation professor of 4.00 and an average value of 3.88 for the validation teachers. For further guidance developed in the lab that has been tested on a limited basis in SMA Negeri 1 Tanah Jawa, with a sample into 2 groups. Group 1 uses existing lab guides, and group 2 using a guide that has been developed. The result show an increase in student learning outcomes of $39 \%$ with a significance level of $<0.05$.
\end{abstract}

Keywords: Guidance lab, research and development, discovery learning.

\section{Pendahuluan}

Salah satu upaya untuk meningkatkan mutu pendidikan adalah melalui pengadaan materi pelajaran yang bermutu (Lee, dkk, 2010). Pembelajaran bermakana dapat terjadi jika koneksi yang dibuat antara informasi yang tersimpan dalam visual dan pendengaran kerja secara bersamaan (Mickell dan Danner, 2007). Apabila guru kimia hanya menguasai terminologi kimia sebagai sains secara hafalan dan dalam proses pembelajaranpun dilakukan secara verbalistis (hafalan), maka hakekat berfikir sains tidak dimiliki guru tersebut, sehingga pembelajaran kimia berlangsung secara monoton, membosankan dan tidak menarik minat siswa dalam belajar kimia (Sunyono, 2009)

Mempelajari ilmu kimia bukan hanya untuk menguasai kumpulan pengetahuan berupa fakta, konsep ataupun prinsip tetapi ilmu kimia merupakan experimental science yang tidak dapat dipelajari hanya melalui membaca, menulis, atau mendengarkan (Jahro, 2009). Sejalan dengan hal tersebut, Tezcam dan Bligin (2004) menyatakan perumpamaan mengenai pembelajaran kimia, 
bahwa seseorang yang belajar menggambar, namun tanpa menggunakan cat dan kanvas atau seseorang yang mencoba belajar bersepeda, namun tanpa menggunakan sepeda sama halnya dengan seseorang yang belajar kimia tanpa melakukan praktikum. Hal ini berarti bahwa pembelajaran kimia paling efektif dapat dilakukan melalui kegiatan praktikum.

Secara umum pendekatan yang sesuai ada tiga pendekatan ilmiah yang dapat dilakukan oleh pendidik untuk memenuhi kebutuhan peserta didik yang beragam, terkhusus dalam memperlajari ilmu kimia, yaitu Pembelajaran Penemuan (Discovery Learning), Pembelajaran Berbasis Proyek (Project Based Learning), dan Pembelajaran Berbasis Masalah (Problem Based Learning). Pada umumnya pendekatan merupakan usaha pendidik untuk meningkatkan motivasi dan minat belajar peserta didik terhadap ilmu kimia dalam upaya untuk meningkatkan prestasi belajar. (Lauresh dalam Zakiah, 2015).

\section{Pembelajaran Penemuan (Discovery} Learning) merupakan model pengajaran yang menekankan pada pentingnya membantu siswa memahami struktur atau ide-ide kunci suatu disiplin ilmu, kebutuhan akan keterlibatan aktif siswa dalam proses belajar, dan keyakinan bahwa pembelajaran sejati terjadi melalui Personal Discovery (penemuan pribadi). Ketika Discovery diterapkan di bidang sains dan ilmu sosial, ia menekankan penalaran induktif dan proses penyelidikan yang menjadi karakter khas metode ilmiah (Arends, 2007). Hal ini sesuai dengan konsep-konsep ilmu kimia yang didapat melalui penyelidikan dan penemuan.

Penuntun praktikum yang dikembangkan dapat bersifat inovatif interaktif yang digunakan dalam pembelajaran kimia. Penuntun praktikum inovatif interaktif ini dapat dilakukan dengan memanfaatkan apa yang ada pada saat ini, misalnya interaksi terhadap lingkungan dan guru, penggunaan Software komputer seperti Microsoft Power Point, Authorware, Micromedia Captive, Macromedia Flash, Cool Audition, Photo Shop, Movi Maker dan lain-lain. Machtmes, dkk (2009) menyatakaan inovasi pembelajaran untuk meningkatakan prestasi belajar siswa pada pembelajaran kimia sangat dibutuhkan karena berhubungan langsung dengan peningkatan kualitas lulusan dalam mengisi lapangan kerja bidang kimia.

Di laboratorium, guru dapat mengembangkan keterlibatan fisik dan mental, serta emosional peserta didik. Peserta didik mendapat kesempatan untuk melatih keterampilan proses agar memperoleh hasil belajar yang maksimal. Pengalaman yang dialami secara langsung dapat tertanam dalam pikirannya lebih lama disbanding dengan hanya mendengar pengalaman yang diceritakan orang lain. Keterlibatan fisik dan mental serta emosional peserta didik diharapkan dapat menumbuhkan kondisi pembelajaran yang dapat meningkatkan rasa percaya diri dan juga perilaku inovatif dan kreatif. Dengan bereksperimen, peserta didik 'diajak' untuk menjadi ilmuwan kimia. Dengan begitu mereka dapat memahami sendiri proses dan konsep kimia sesuai dengan hasil yang diperoleh selama pembelajaran.

Berdasarkan permasalahan diatas, peneliti bermaksud untuk melakukan pengembangan penuntun praktikum SMA dengan mengintegrasikan discovery learning (pembelajaran penemuan) ke dalam penuntun 
praktikum tersebut. Secara umum penelitian ini bertujuan untuk:

1. Menganalisis buku penuntun praktikum yang digunakan menggunakan angket kelayakan isi.

2. Menghasilkan buku penuntun praktikum yang telah dikembangkan yang memenuhi standart BSNP.

3. Menghasilkan buku penuntun praktikum yang telah dikembangkan yang memenuhi kelayakan untuk dipergunakan dalam pembelajaran.

4. Mengetahui efektifitas dan efisiensi buku penuntun praktikum yang telah dikembangkan terhadap peningkatan hasil belajar siswa.

\section{Metode Penelitian}

Penelitian telah dilaksanakan di Kabupaten Simalungun, Sumatera Utara. Pemilihan lokasi penelitian bersifat terbatas, melalui pertimbangan lokasi yang dapat dijangkau oleh penulis. Penelitian akan dilaksanakan pada bulan Nopember 2015-Pebruari 2016.

Sampel penelitian diambil secara purposive sampling. Sampel merupakan siswa/i kelas XII SMA Negeri 1 Tanah Jawa yang telah mempelajari materi kimia unsur. Sampel dibagi kedalam 2 kelompok, yaitu Kelompok I menggunakan buku penuntun praktikum yang ada dan Kelompok II yang menggunakan buku penuntun praktikum yang telah dikembangkan. Jumlah sampel yang diambil dari tiap kelompok adalah 16 orang.

Jenis penelitian ini adalah penelitian dan pengembangan (research and development) dan eksperimen. Hasil belajar menggunakan penuntun praktikum terkembangkan di ukur pada akhir penelitian. Penelitian dan pengembangan (research and development) merupakan penelitian yang digunakan untuk mengahasilkan produk tertentu dan menguji keefektifan produk tersebut (Sugiyono, 2010).

Pelaksanaan penelitian untuk mendapatkan data penelitian terdiri dari:

1. Menganalisis penuntun praktikum yang tersedia.

2. Menyusun penuntun praktikum inovatif dan interaktif sesuai dengan sintaks Discovery Learning.

3. Standarisasi penuntun praktikum sesuai Standar Nasional Pendidikan

4. Uji kelayakan penuntun praktikum oleh para validator ahli (Dosen dan Guru)

5. Uji coba terbatas penuntun praktikum di SMA Negeri 1 Tanah Jawa

6. Hasil uji coba terbatas penuntun praktikum di SMA Negeri 1 Tanah Jawa

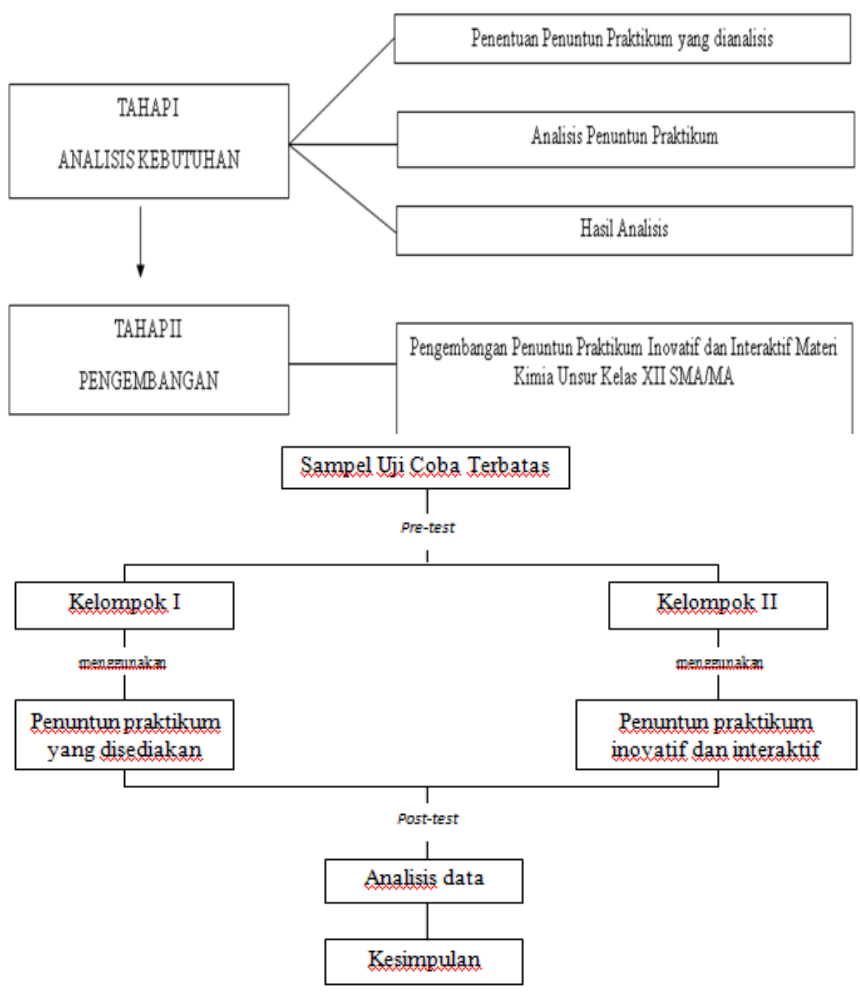

Gambar 3.2. Prosedur Uji Coba Terbatas Penuntun Praktikum.

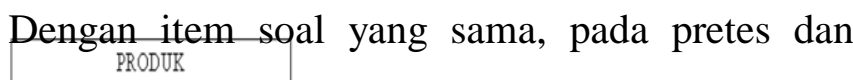
postes kelompok I melakukan tes dengan soal yang disajikan pada lembaran kertas soal, 
sedangkan kelompok II melakukan tes dengan soal yang disajikan dalam media exe-learning.

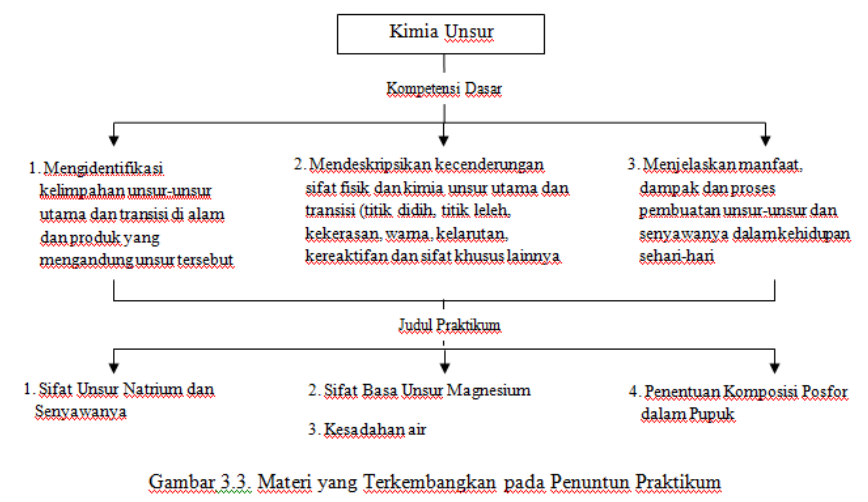

Teknik yang digunakan untuk mengumpulkan dat dalam penelitian ini adalah teknik tes. Data yang dikumpulkan diperoleh dari hasil belajar yang berupa hasil dari pre-tes dan post-tes.

Teknik analisis data yang digunakan untuk menguji hipotesis, sebelum menguji hipotesis dilakukan terlebih dahulu uji prasyarat, yaitu (1) uji normalitas, (2) uji homogenitas, dan (3) data dari angket.

\section{Hasil dan Pembahasan}

Salah satu penuntun praktikum yang beredar adalah penuntun praktikum dari penerbit Pudak Scientific sesuai kurikulum tingkat satuan pendidikan (KTSP). Buku ini berisi tentang analisis kurikulum, matrikulasi, pengenalan alat dan bahan, teknik laboratorium dan pembuatan larutan. Buku tersebut menyajikan percobaanpercobaan praktikum yang dapat dilakukan untuk pelajaran kimia kelas XII SMA untuk semester ganjil dan semester genap.

Dari hasil analisis diperoleh nilai rata-rata dari angket sebaran dosen sebesar 4,04 dan nilai rata-rata untuk angket sebaran guru sebesar 3,80. Setelah dianalisis dan mengetahui komponen penyusunan penuntun praktikum yang beredar, dalam hal ini buku penuntun praktikum kimia SMA kelas XII penerbit Pudak Scientific, maka dilakukanlah pengembangan penuntun praktikum tersebut dengan materi kimia unsur. Pengembangan penuntun praktikum ini disesuaikan dengan kurikulum tingkat satuan pendidikan (KTSP) yang inovatif dan interaktif terintegrasi dengan discovery learning.

Pengembangan ini disesuaikan dengan kompetensi dasar (KD) dan indikator sesuai dengan silabus. Penuntun praktikum yang dikembangkan ini merupakan penuntun praktikum yang inovatif dan interaktif, yang di dalamnya tersedia compact disc (CD) pembelajaran. Dimana didalam CD pembelajaran tersebut terdapat aplikasi exe-learning yang menjelaskan beberapa manfaat unsur-unsur terhadap kehidupan manusia dan didalam aplilkasi tersebut juga terdapat soal latihan interaktif materi kimia unsur.

Penuntun praktikum kimia materi kimia unsur yang inovatif dan interaktif terintegrasi discovery learning yang telah disusun dan dikembangkan sesuai kurikulum tingkat satuan pendidikan (KTSP) selanjutnya distandarisasi melalaui uji validitas menggunakan angket oleh responden yang terdiri dari 2 orang dosen kimia Universitas Negeri Medan dan 25 orang guru kimia SMA. Adapun hasil dari pada analisis penuntun praktikum kimia yang telah divalidasikan oleh dosen dan guru adalah sebagai berikut:

\section{Hasil Validasi Penuntun Praktikum kepada}

\section{Dosen}

Responden dosen yang dipilih adalah 2 dosen kimia di Universitas Negeri Medan dengan latar belakang pendidikan S3 (Doktor) dan telah memiliki pengalaman mengajar yang lama. Angket yang diberikan kepada responden dosen 
berupa angket standar penilaian penuntun praktikum kimia sesuai BSNP dengan menilai beberapa aspek kelayakan, antara lain aspek kelayakan isi, kelayakan bahasa, kelayakan penyajian, dan kelayakan kegrafikaan. Data dari validasi tersebut disajikan dalam lampiran 6 , dan hasilnya dapat dilihat pada diagram yang ada pada gambar 1.1.

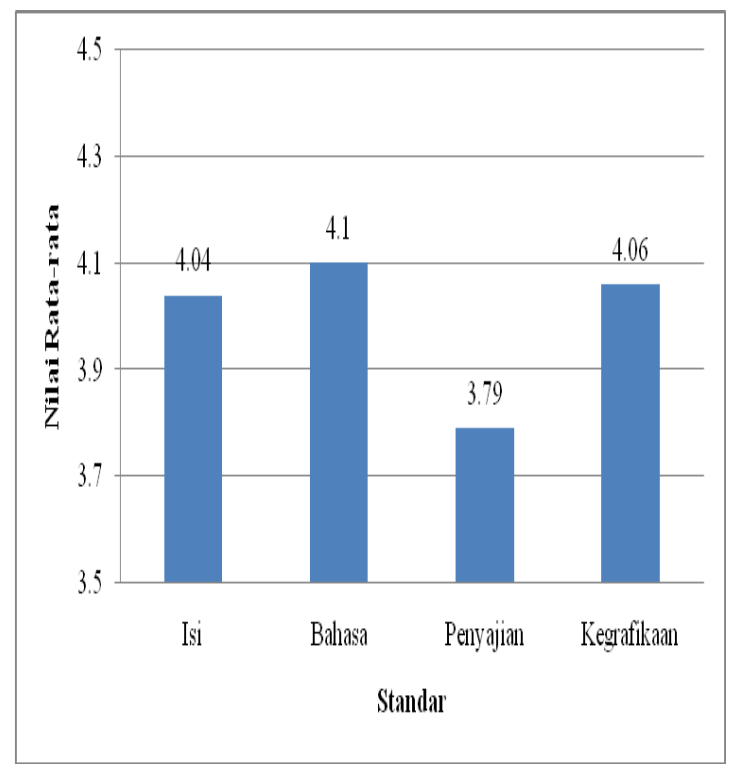

Gambar 1.1. Hasil validasi uji kelayakan penuntun praktikum yang telah dikembangkan sesuai dengan standar nasional pendidikan

Berdasarkan hasil validasi uji kelayakan penuntun praktikum terintegrasi discovery learning oleh 2 orang dosen tersebut didapat bahwa penuntun praktikum tersebut sudah layak dan tidak perlu direvisi. Untuk kelayakan isi, nilai rata-rata yang diperoleh sebesar 4,04, untuk kelayakan bahasa diperoleh rata-rata sebesar 4,1, untuk kelayakan penyajian diperoleh rata-rata sebesar 3,79, dan untuk kelayakan kegrafikaan diperoleh hasil rata-rata sebesar 4,06. Didalam angket tersebut, responden menambahkan beberapa saran-saran berupa penambahan ilustrasi praktikum berupa gambar dan penambahan rujukan pustaka.

\section{Hasil Validasi Penuntun Praktikum kepada} Guru SMA
Responden yang dipilih adalah 25 orang guru kimia SMA dengan latar belakang pendidikan minimal S1. Instrumen yang digunakan merupakan angket yang sudah terstandarisasi dan sudah pernah digunakan oleh peneiti sebelumnya yang terkait dengan standarisasi kelayakan penuntun praktikum. Adapun hasil dari validasi oleh responden guru adalah sebagai berikut :

\section{- Aspek Cakupan Praktikum}

Dalam aspek cakupan praktikum, terdapat 4 komponen yang terkait di dalamnya, antara lain; (a) keluasan praktikum; (b) kesesuaian praktikum dengan SK dan KD; (c) kesesuaian tujuan praktikum dengan indikator pembelajaran; dan (d) kesesuaian prosedur praktikum dengan model pembelajaran yang diterapkan. Dari keempat komponen tersebut diperoleh nilai rata-rata secara berurut sebesar 3,6; 3,96; 3,76; dan 3,96 dengan nilai rata-rata keseluruhan sebesar 3,82, yang artinya penuntun tersebut telah layak dan tidak perlu direvisi. Hasil uji kelayakan untuk aspek cakupan praktikum dapat dilihat pada diagram yang ada pada gambar 1.2.

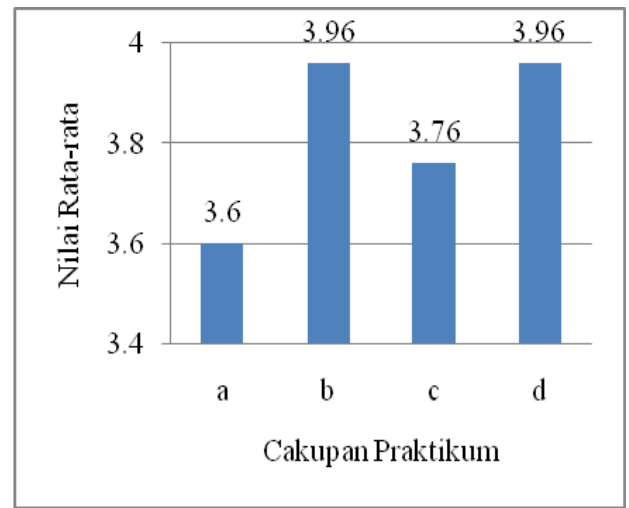

Gambar 1.2. Hasil validasi uji kelayakan penuntun praktikum yang telah dikembangkan berdasarkan cakupan praktikum

\section{- Aspek Sistematika Penyajian}

Dalam aspek sistematika penyajian, terdapat 3 komponen yang terkait di dalamnya, 
antara lain; (a) kerunutan susunan penyajian; (b) identitias tabel, gambar, dan lampiran; dan (c) prosedur praktikum dijelaskan secara sistematis dan jelas. Dari ketiga komponen tersebut diperoleh nilai rata-rata secara berurut sebesar 4,08; 3,68; dan 4 dengan nilai rata-rata keseluruhan sebesar 3,92, yang artinya penuntun tersebut telah layak dan tidak perlu direvisi. Hasil uji kelayakan untuk aspek sistematika penyajian dapat dilihat pada diagram yang ada pada gambar 1.3 .

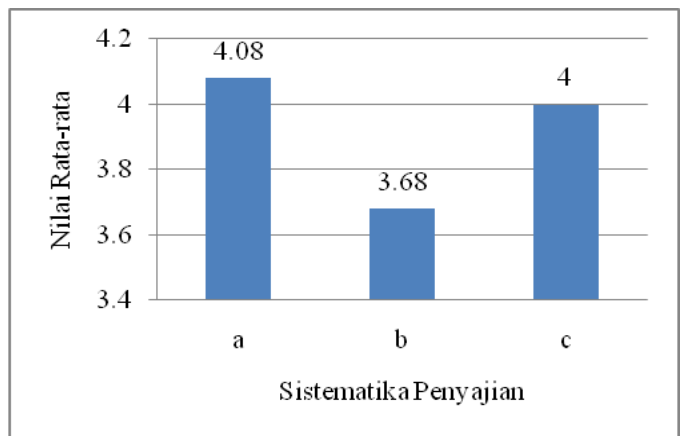

Gambar 1.3. Hasil validasi uji kelayakan penuntun praktikum yang telah dikembangkan berdasarkan sistematika penyajian

\section{- Aspek Mengandung Wawasan Produktifitas}

Dalam aspek mengandung wawasan produktifitas, terdapat 2 komponen yang terkait di dalamnya, antara lain; (a) menumbuhkan etos kerja siswa; dan (b) menumbuhkan semangat berinovasi, kreatif dan berfikir kritis pada siswa. Dari kedua komponen tersebut diperoleh nilai rata-rata secara berurut sebesar 4,04 dan 3,96 dengan nilai rata-rata keseluruhan sebesar 4, yang artinya penuntun tersebut telah layak dan tidak perlu direvisi. Hasil uji kelayakan untuk aspek mengandung wawasan produktifitas dapat dilihat pada diagram yang ada pada gambar 1.4.

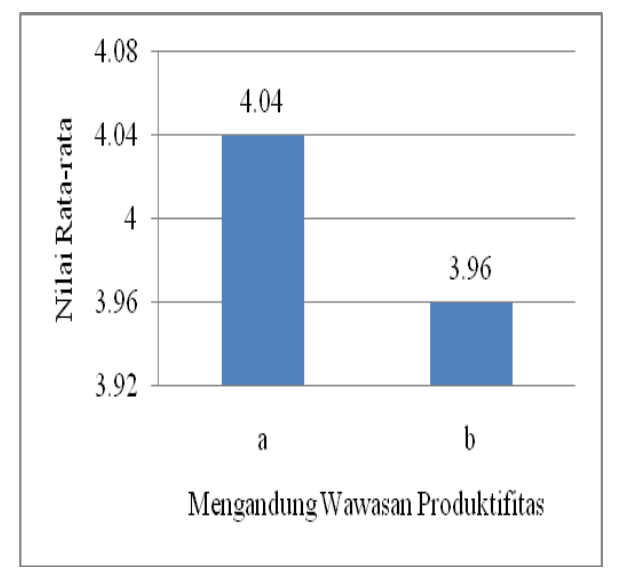

Gambar 1.4. Hasil validasi uji kelayakan penuntun praktikum yang telah dikembangkan berdasarkan mengandung wawasan produktifitas

\section{- Aspek Merangsang Keingintahuan}

Dalam aspek merangsang keingintahuan, terdapat 2 komponen yang terkait di dalamnya, antara lain; (a) menumbuhkan rasa ingin tahu siswa; dan (b) memberi tantangan untuk lebih jauh. Dari kedua komponen tersebut diperoleh nilai rata-rata secara berurut sebesar 3,92 dan 4,08 dengan nilai rata-rata keseluruhan sebesar 4, yang artinya penuntun tersebut telah layak dan tidak perlu direvisi. Hasil uji kelayakan untuk aspek merangsang keingintahuan dapat dilihat pada diagram yang ada pada gambar 1.5.

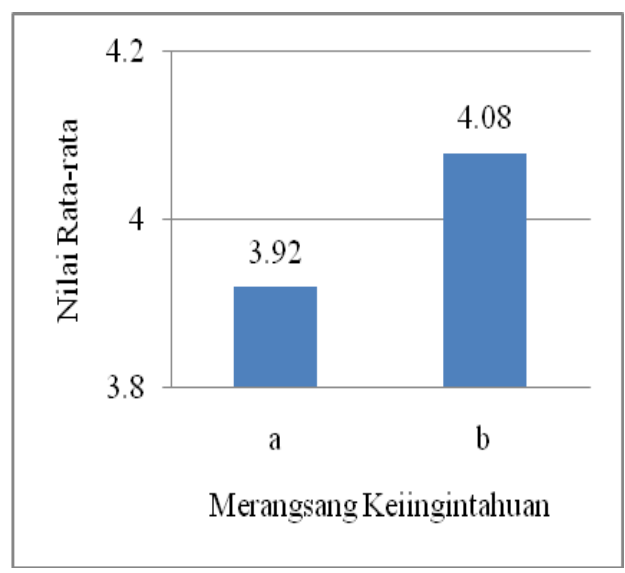

Gambar 1.5. Hasil validasi uji kelayakan penuntun yang telah dikembangkan berdasarkan merangsang keiingintahuan

- Aspek Mengembangkan Kecakapan Hidup (Life Skill)

Dalam aspek mengembangkan kecakapan hidup (life skill), terdapat 3 komponen yang 
terkait di dalamnya, antara lain; (a) mengembangkan kecakapan personal; (b) mengembangkan kemampuan psikomotor siswa; dan (c) mengembangkan kecakapan akademik. Dari ketiga komponen tersebut diperoleh nilai rata-rata secara berurut sebesar 3,96; 3,88; dan 3,8 dengan nilai rata-rata keseluruhan sebesar 3,88, yang artinya penuntun tersebut telah layak dan tidak perlu direvisi. Hasil uji kelayakan untuk aspek mengembangkan kecakapan hidup (life skill) dapat dilihat pada diagram yang ada pada gambar 1.6.

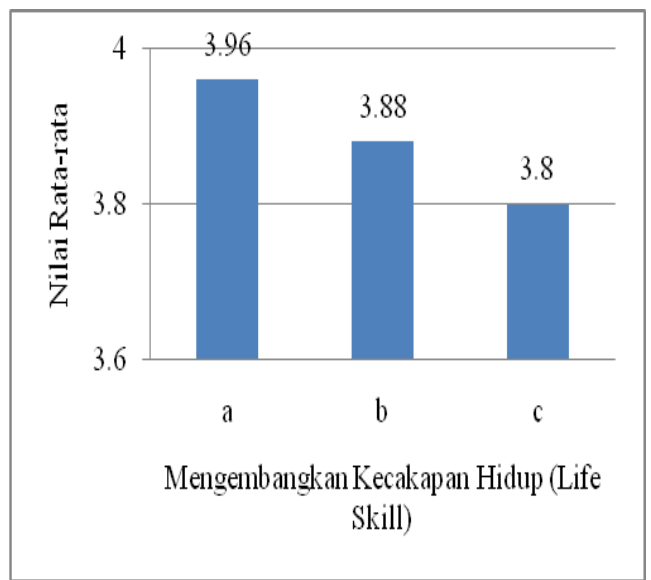

Gambar 1.6. Hasil validasi uji kelayakan penuntun praktikum yang telah dikembangkan berdasarkan mengembangkan kecakapan hidup (life skill)

\section{- Aspek Desain}

Dalam aspek desain, terdapat 2 komponen yang terkait di dalamnya, antara lain; (a) penyajian gambar, tabel dan lambang; dan (b) interaktif. Dari kedua komponen tersebut diperoleh nilai rata-rata secara berurut sebesar 3,6 dan 3,68 dengan nilai rata-rata keseluruhan sebesar 3,64, yang artinya penuntun tersebut telah layak dan tidak perlu direvisi. Hasil uji kelayakan untuk aspek desain dapat dilihat pada diagram yang ada pada gambar 1.7.

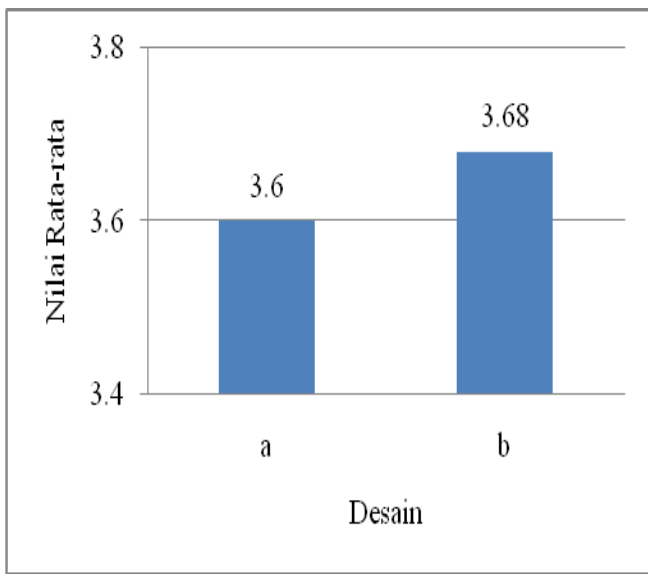

Gambar 1.7. Hasil validasi uji kelayakan penuntun praktikum yang telah dikembangkan berdasarkan desain

\section{- Aspek Bahasa}

Dalam aspek bahasa, terdapat 3 komponen yang terkait di dalamnya, antara lain; (a) sesuai dengan perkembangan peserta didik; (b) komunikatif; dan (c) konsistensi penggunaan istilah dan simbol pada penuntun praktikum. Dari ketiga komponen tersebut diperoleh nilai rata-rata secara berurut sebesar 3,96; 3,96; dan 3,84 dengan nilai rata-rata keseluruhan sebesar 3,92, yang artinya penuntun tersebut telah layak dan tidak perlu direvisi. Hasil uji kelayakan untuk aspek bahasa dapat dilihat pada diagram yang ada pada gambar 1.8.

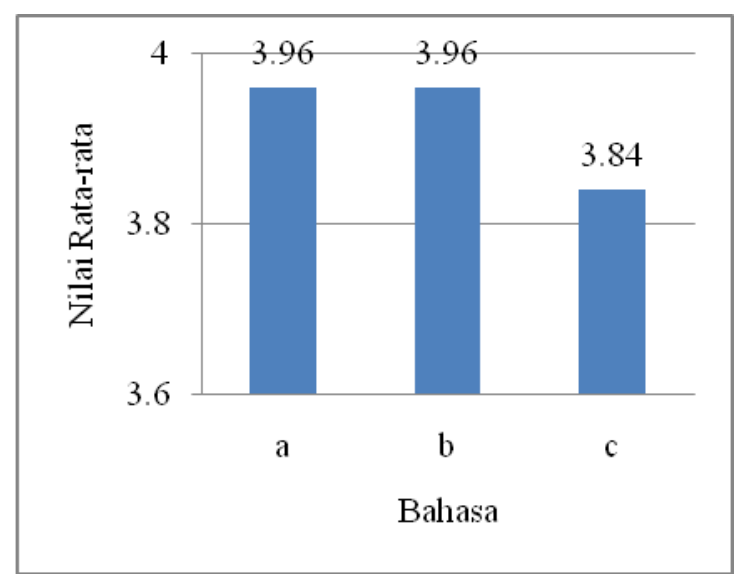

Gambar 1.8. Hasil validasi uji kelayakan penuntun praktikum yang telah dikembangkan berdasarkan bahasa

Untuk mengetahui peningkatan hasil belajar dengan pembelajaran menggunakan penuntun praktikum yang telah dikembangkan ini melibatkan 2 kelompok siswa, dengan masing- 
masing kelompok berjumlah 16 orang. Kelompok 1 pembelajaran menggunakan penuntun praktikum yang beredar (kelompok kontrol) dan kelompok 2 menggunakan penuntun praktikum yang telah dikembangkan (kelompok eksperimen).

Pada masing-masing kelompok dilakukan terlebih dahulu tes awal (pre test) yang bertujuan untuk mengetahui kemampuan awal siswa, dan setelah diberi perlakuan kemudian siswa diberikan tes akhir (post test). Dimana pada kelompok 1, soal tes disajikan dalam bentuk kertas biasa dan untuk soal tes kelompok 2 disajikan secara interaktif dalam bentuk exe-learning.

Perolehan nilai rata-rata pre test pada kelompok 1 adalah 55 dan kelompok 2 memperoleh nilai rata-rata sebesar 43. Sedangkan untuk post test pada kelompok 1 diperoleh nilai rata-rata sebesar 75 dan kelompok 2 memperoleh nilai rata-rata sebesar 82 . Berdasarkan hasil pre test dan post test siswa,terdapat perbedaan nilai rata-rata sehingga perlu ditentukan nilai gain ternormalisasi hasil belajar kimia pada kelompok tersebut.

Perolehan nilai gain ternormalisasi pada kelompok 1 dan kelompok 2 secara berturut adalah 0,19 dan 0,3. Dapat disimpulkan bahwa nilai rata-rata gain ternormalisasi yang terendah terdapat pada kelompok 1, yaitu kelompok yang menggunakan buku penuntun praktikum yang beredar, sedangkan pada kelompok 2 yang menggunakan penuntun praktikum yang telah dikembangkan memperoleh rata-rata gain ternormalisasi yang lebih tinggi.

Penuntun praktikum yang telah divalidasi kemudian diperbaiki. Perbaikan terhadap penuntun praktikum dilakukan berdasarkan saran dan masukan yang telah diberikan oleh responden.
Saran berupa penambahan gambar ilustrasi dan rujukan pustaka ditambahkan kemudian untuk produk akhir dari pengembangan penuntun praktikum yang inovatif dan interaktif terintegrasi discovery learning materi kimia unsur kelas XII SMA.

\section{Kesimpulan}

Berdasarkan hasil analisis data dan pembahasan maka dapat disimpulkan bahawa:

1. Buku penuntun praktikum yang ada pada saat ini telah memenuhi standar BSNP.

2. Buku penuntun praktikum yang telah dikembangkan telah memenuhi standar BSNP.

3. Buku penuntun praktikum yang telah dikembangkan sudah memenuhi kelayakan untuk dipergunakan dalam pembelajaran dan tidak perlu direvisi.

4. Buku penuntun praktikum yang telah dikembangkan efektif dan efisien terhadap peningkatan hasil belajar siswa pada materi kimia unsur.

\section{Daftar Pustaka}

BSNP, (2006), Panduan Penyusunan Bahan Ajar, Depdiknas, Jakarta.

Fransisca., (2010), Pengembangan Buku Penuntun Praktikum Kimia SMA Kelas X sesuai dengan Tuntutan Kurikulum Tingkat Satuan Pendidikan (KTSP), Tesis, Program Pascasarjana, Unimed, Medan.

Jahro, I.S., (2009), Analisis Penerapan Metode Praktikum pada Pembelajaran Ilmu Kimia di Sekolah Menengah Atas, Jurnal Pendidikan Kimia, 1:20-26.

Jaya, H., (2012), Pengembangan Laboratorium Virtual untuk Kegiatan Praktikum dan Memfasilitasi Pendidikan Karakter di SMK, Jurnal Pendidikan Vokasi, 2(1): 81-90. 
Johari, J.M.C., dan Rachmawati, M., (2012), Chemistry for Senior High School Grade XII, Esis, Jakarta.

Machtmes, K., Johnson, E., Fox, J., and Burke, M.S., (2009), Teaching Qualitative Research Methods Through Service Learning, The Qualitative Report 4(1): 155-165.

Situmorang, H., Situmorang, M., (2009), Keefektifan Media Komputer Dalam Meningkatkan Penguasaan Kimia Siswa Sekolah Menengah Kejuruan Pada Pengajaran Materi dan Perubahannya, Jurnal Pendidikan Matematika dan Sains 3(1) :45-51

Tezcam, H., and Bilgin, E., (2004), Affects of Laboratory Method and Other Factors on
The Students Success in The Teaching of The Vation Subject at The High School, The Journal of Gazi Educational Faculty, 24: 175-191.

Tim Pudak Scientific, (2008), Kimia, Pudak Scientific, Bandung.

Tuysuz, C.,(2010), The Effect of the Virtual Laboratory on Students' Achievement and Attitude in Chemistry. IOJES 2(1): 37-53.

Zakiah., (2015), Pengembangan Penuntun Praktikum Tipe Discovery dan Project Based Learning pada Pembelajaran Larutan Elektrolit dan Nonelektrolit di SMA, Jurnal Pendidikan Kimia, 7(11): 70-79. 